\title{
STUDY OF SUBSIDING TROUGH EXPANSION OVER TWIN TUBE TBM METRO TUNNEL
}

\section{A. SIEMIŃSKA-LEWANDOWSKA ${ }^{1}$, R. KUSZYK ${ }^{2}$}

\begin{abstract}
The main problem of tunnelling with use of TBM in highly dense urban areas is to assign the range of subsiding trough and the impact of tunnelling works on existing buildings and underground or road infrastructure. The paper presents the results of settlements calculations over twin tube metro tunnel using analytical, empirical methods. The tunnel external diameter is $6,5 \mathrm{~m}$; the overburden vary from $5 \mathrm{~m}$ to $8 \mathrm{~m}$; the distance between tunnel axis is $14 \mathrm{~m}$. Because of quaternary soils and high water table level the TBM type EBP was chosen as the method of tunnel construction. At the length of $502 \mathrm{~m}$ of tunnel the monitoring system was carried out in 22 cross sections. The results of settlements monitoring were compared with the values of analytical calculations.
\end{abstract}

Keywords: metro tunnel; settlements calculation; subsiding through; TBM EPB

\section{INTRODUCTION}

Surface settlement is one of the main issue of tunnelling in an urban environment. In many countries there are instructions for easy predict an area of influence for deep excavation but this is mainly for stations. In Poland there are several authors proposed such solution in comparison with real deformations: Mitew-Czajewska [7], [8], Siemińska-Lewandowska \& Mitew-Czajewska [14]. An accurate prediction of the tunnelling-induced displacement field is hence a key element of the design studies of any urban tunnel. The main problem of tunnelling with use of TBM is to assign the range of subsiding trough and the impact of tunnelling works on existing buildings and underground or road

\footnotetext{
${ }^{1}$ Prof., DSc., PhD., Eng., Warsaw University of Technology, Faculty of Civil Engineering, L.Kaczynskiego Str. 16, 00-637 Warsaw, Poland, e-mail: a.lewandowska@il.pw.edu.pl

${ }^{2}$ MSc., Warsaw University of Technology, Faculty of Civil Engineering, L.Kaczynskiego Str. 16, 00-637 Warsaw, Poland, e-mail: r.kuszyk@il.pw.edu.pl
} 
infrastructure. In the paper authors present outcomes of surface deformation for typical urban area in Warsaw with masonry buildings nearby the line - concrete or brick one, about 60-70 years old most of them.

TBM tunnelling in Poland starts to develop quickly - there are several projects on-going or will just start but there are no applicable design guidelines for settlement prediction dedicated to local quaternary deposits represented by consolidated glacial tilts and compacted glacial sands. The only one local recommendation is presented by the Instruction of Building Institute [16] where two type of the zones of influence are presented. This solution is mainly for deep excavations not directly for tunnelling design. Also it is possible to use ITA guidelines [17] but this should takes into account adaptation to local soil type conditions.

In practice, empirical methods are most commonly used for subsiding trough expansion calculations. They are more or less combined with analytical methods or finite element computations, and could be calibrated with data from case studies. Analytical methods are based on simplifying assumptions in terms of geometry and ground conditions. Scientific literature provides numerous empirical and analytical formulations: Peck, 1969 [12], Oteo, 1979 [11], Clough and Schmidt, 1981 [2], Attewell and Woodman, 1982 [1], New and O’Reilly, 1982 [10], Herzog, 1985 [3], Sagaseta, 1987 [13], Verruijt and Booker, 1996 [15], Loganathan and Poulos, 1998 [5]. Using empirical formula the subsiding through over single tunnel can be asset. In case of twin tube tunnels the superposition of two single subsiding through is the most commonly used practice. This, does not cover the real settlement distribution as a monitoring results.

\section{TUNNEL DESCRIPTION}

\subsection{General DATA}

The twin tube metro tunnel of total length of $502 \mathrm{~m}$ was performed using TBM EPB of $6.5 \mathrm{~m}$ in diameter. The distance between the tunnel axis was $14,0 \mathrm{~m}$. One ring of segmental lining $0,3 \mathrm{~m}$ thick was composed of 5 segments. The technical data of the EPB machine were as follow:

Outer diameter of the segmental lining

$6,0 \mathrm{~m}$

Inner diameter of the segmental lining

$5,4 \mathrm{~m}$

Maximal torque

$1,8 \div 3,8 \mathrm{MNm}$

Face support pressure

$2,5 \div 3,4$ bar

Cover

$5 \div 8 \mathrm{~m} \mathrm{bgl}$ 
The typical cross section of twin tube metro tunnel is shown on Fig. 1.
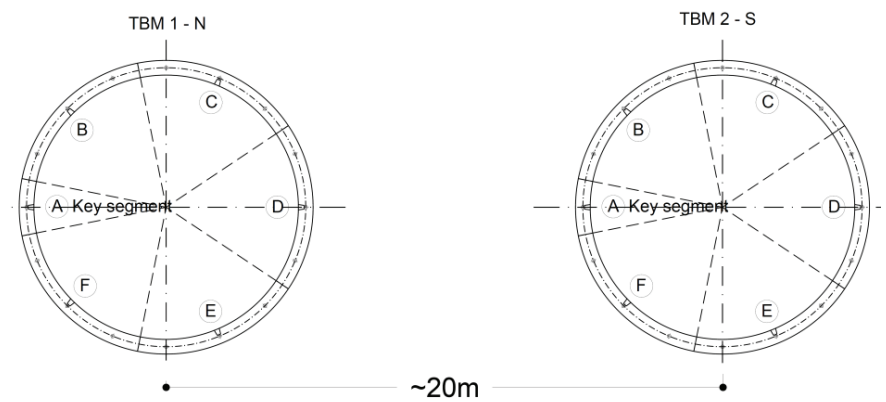

Fig. 1. Cross section of twin tube metro tunnel

\subsection{GEOTECHNICAL CONDITION}

The tunnel is entirely located in heterogeneous quaternary soils. The geological model of the subsoil is shown on Fig. 2.

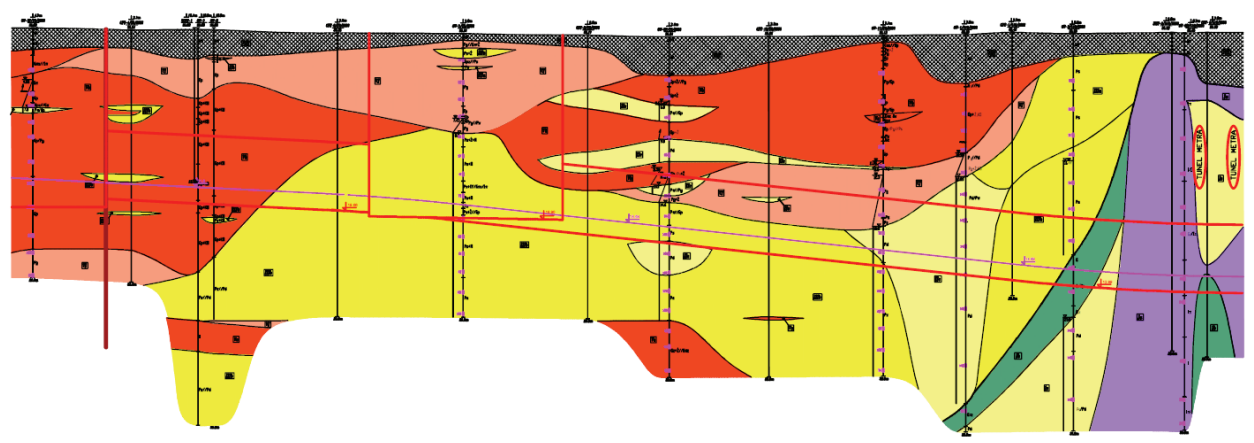

Fig. 2. Geological profile

Geological model along tunnels consists of:

- man made embankment (sand-clay-bricks) thickness about $1 \div 6 \mathrm{~m}$;

- Warta glaciation deposits ( $\mathrm{saCl}$, sasiCl, sisaCl) thickness about $4 \mathrm{~m}$ with sandy interbeddings (MSa); 
- Odra glaciation deposits ( $\mathrm{saCl}$, sasiCl, sisaCl) thickness from $19 \mathrm{~m}$ (East site) to $2 \div 5 \mathrm{~m}$ (West site);

- saturated sandy and gravel deposits.

Both field and laboratory tests were done to carry out geotechnical parameters for each soil layer. Insitu test consist mainly of core recovery drillings, static penetration test and Marchetti dilatometer test. Also there were geophysical cross-hole test performed for better soil homogeneity and modulus characterization. Advanced laboratory tests were applied in triaxial apparatus with bender element measurements. Finally several properties were described as: mechanical one, earth pressure coefficient $\mathrm{K}_{0}$, OCR, permeability, elastic modulus and oedometer modulus.

\subsection{DESCRIPTION OF SETTLEMENTS MONITORING SYSTEM}

Monitoring system was designed to check surface displacements during TBM drive. The system based on measuring devices for global deformation of subsoil, differences in pore pressure and stresses in the tunnel lining. The system based on:

- devices for deep horizontal deformation measurements (inclinometers INC);

- devices for deep vertical deformation measurements (extensometers EXT);

- ground benchmarks (GP) for surface deformation measurements;

- piezometers (PIEZ) located in saturated soil to control water level changes along tunnels;

- benchmarks, mirrors and crack-meters on the buildings located in the area of the TBM influence for structure control and cracks propagation;

- devices dedicated to measure deformation and stresses in the tunnel lining because of overburden load.

For the analyzed metro tunnels with $502 \mathrm{~m}$ length, there were installed two full monitoring sections no. D1101 and D1113. For each section there were installed:

- 3 inclinometer pipes with electric probes (INC),

- 2 extensometers with triple rod (EXT),

- 4 piezometers with Casagrande filter (PIEZ),

$-5 \div 7$ ground benchmarks.

For the rest 21 monitoring sections there were installed only 5 to 7 ground benchmarks. The scheme of typical monitoring section along metro line presents Fig. 3. Scheme of geological conditions for each of the analyzed sections no. D1101, D1103, D1104, D1106, D1111 presents Fig. 5-9. 


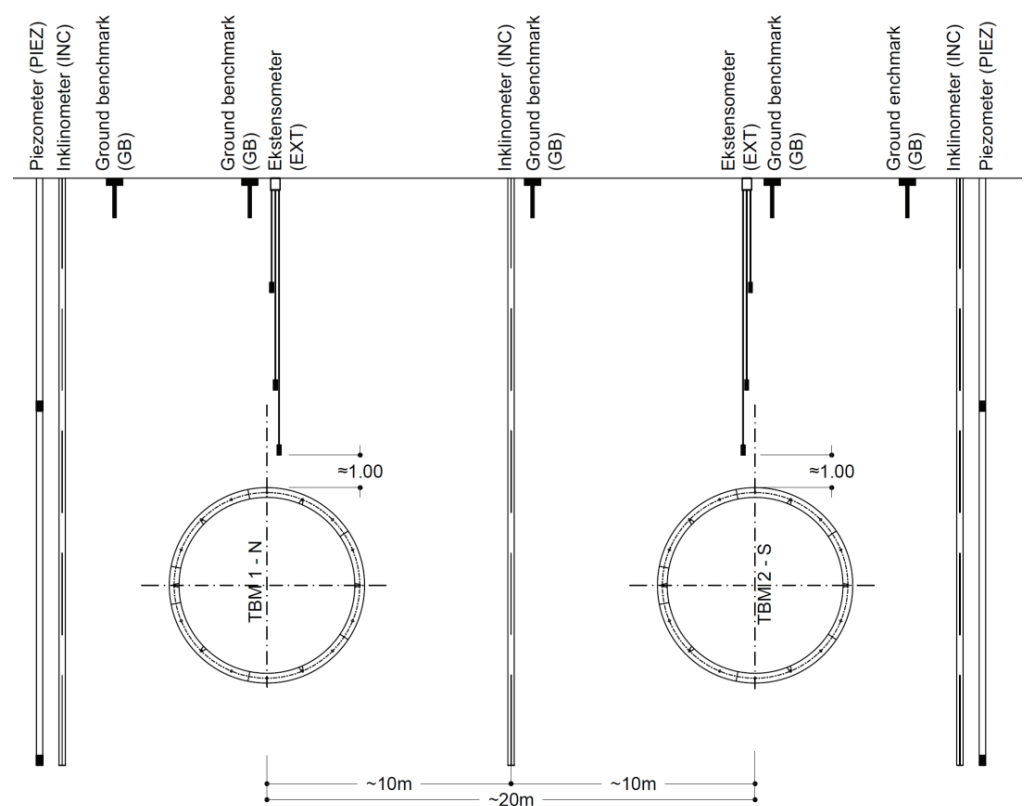

Fig. 3. Typical full monitoring section

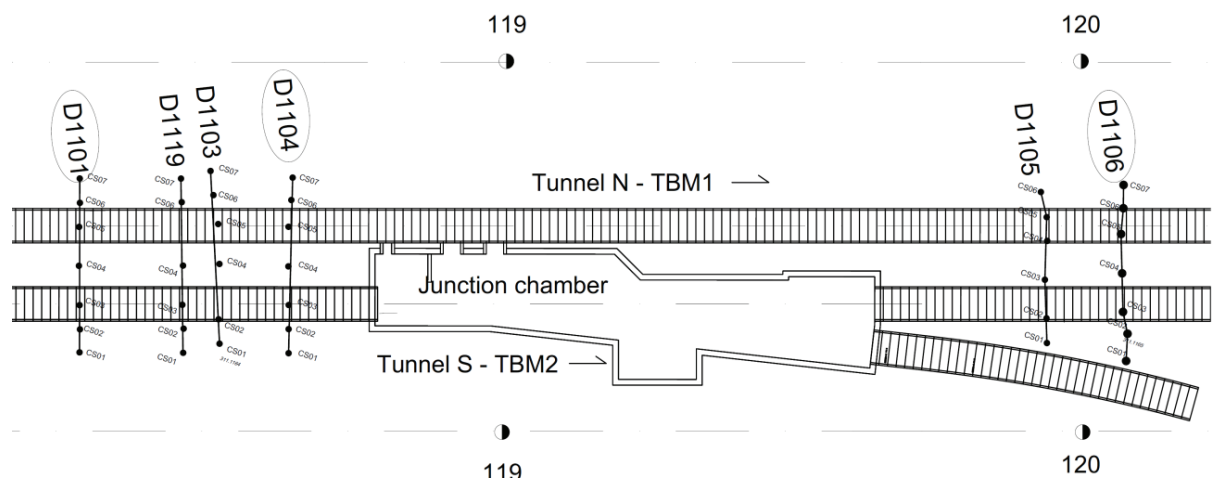

Fig. 4. Location of the monitoring sections no. 1101, 1104 and 1106

For empirical analysis of settlement distribution on the twin tunnel sector, there were extracted 8 representative monitoring sections. 3 of them where located in typical quaternary deposits presented on Fig. 4. The paper presents outcomes for section no. 1101, 1104 and 1106. For each of this section, 
below (Fig. $5 \div 7$ ) there are presented general schemes of soil conditions including information about: thickness of each soil layer and type of soil together with geotechnical parameters dedicated to each leyer. All this informations contain Tab. 1 to 3.

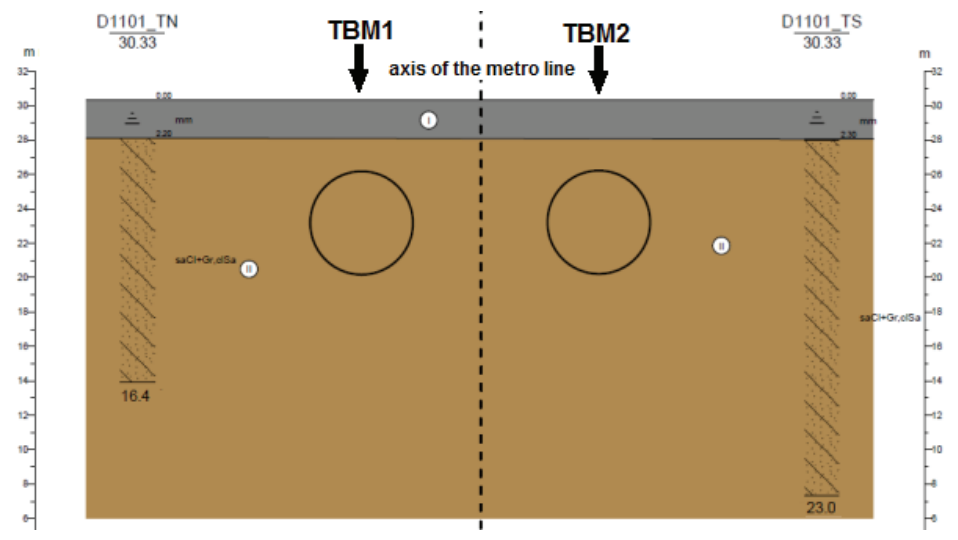

Fig. 5. Geological scheme of the section no. 1101

Table 1. Soil properties in section no. 1101

\begin{tabular}{|c|c|c|c|c|c|c|}
\hline $\begin{array}{c}\text { Thickness of } \\
\text { the layer } \\
{[\mathrm{m}]}\end{array}$ & $\begin{array}{c}\text { No. of } \\
\text { the layer }\end{array}$ & $\begin{array}{c}\text { Type of the } \\
\text { soil }\end{array}$ & $\begin{array}{c}\text { Bulk } \\
\text { density } \\
\rho\left[\mathrm{g} / \mathrm{cm}^{3}\right]\end{array}$ & $\begin{array}{c}\text { Friction } \\
\text { angel } \\
\phi^{\prime}\left[{ }^{0}\right]\end{array}$ & $\begin{array}{c}\text { Cohesion } \\
\mathrm{c}^{\prime}[\mathrm{kPa}]\end{array}$ & $\begin{array}{c}\text { Modulus } \\
\mathrm{E}[\mathrm{MPa}]\end{array}$ \\
\hline 2,2 & I & Man made & 1,90 & 23 & 1 & 10 \\
\hline 15,0 & II & sasiCl & 2,10 & 25 & 8 & 70 \\
\hline
\end{tabular}

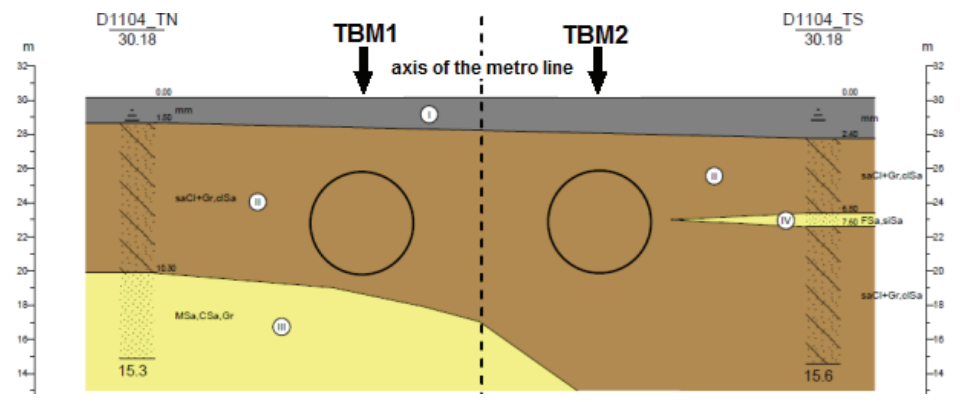

Fig. 6. Geological scheme of the section no. 1104 
Table 2. Soil properties in section no. 1104

\begin{tabular}{|c|c|c|c|c|c|c|}
\hline $\begin{array}{c}\text { Thickness of } \\
\text { the layer } \\
{[\mathrm{m}]}\end{array}$ & $\begin{array}{c}\text { No. of } \\
\text { the layer }\end{array}$ & $\begin{array}{c}\text { Type of the } \\
\text { soil }\end{array}$ & $\begin{array}{c}\text { Bulk } \\
\text { density } \\
\rho\left[\mathrm{g} / \mathrm{cm}^{3}\right]\end{array}$ & $\begin{array}{c}\text { Friction } \\
\text { angel } \\
\phi^{\prime}\left[{ }^{0}\right]\end{array}$ & $\begin{array}{c}\text { Cohesion } \\
\mathrm{c}^{\prime}[\mathrm{kPa}]\end{array}$ & $\begin{array}{c}\text { Modulus } \\
\mathrm{E}[\mathrm{MPa}]\end{array}$ \\
\hline 1,9 & I & Man made & 1,90 & 23 & 1 & 10 \\
\hline 8,8 & II & sasiCl & 2,10 & 25 & 8 & 70 \\
\hline 5,0 & III & $\mathrm{MSa} / \mathrm{CSa}$ & 2,05 & 38 & 0 & 120 \\
\hline
\end{tabular}

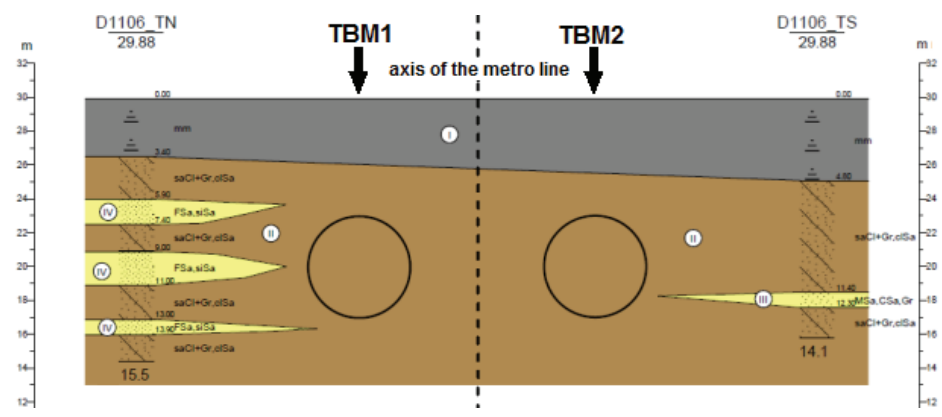

Fig. 7. Geological scheme of the section no. 1106

Table 3. Soil properties in section no. 1106

\begin{tabular}{|c|c|c|c|c|c|c|}
\hline $\begin{array}{c}\text { Thickness of } \\
\text { the layer } \\
{[\mathrm{m}]}\end{array}$ & $\begin{array}{c}\text { No. of } \\
\text { the layer }\end{array}$ & $\begin{array}{c}\text { Type of the } \\
\text { soil }\end{array}$ & $\begin{array}{c}\text { Bulk } \\
\text { density } \\
\rho\left[\mathrm{g} / \mathrm{cm}^{3}\right]\end{array}$ & $\begin{array}{c}\text { Friction } \\
\text { angel } \\
\phi^{\prime}\left[{ }^{0}\right]\end{array}$ & $\begin{array}{c}\text { Cohesion } \\
\mathrm{c}^{\prime}[\mathrm{kPa}]\end{array}$ & $\begin{array}{c}\text { Modulus } \\
\mathrm{E}[\mathrm{MPa}]\end{array}$ \\
\hline 3,6 & I & Man made & 1,90 & 23 & 1 & 10 \\
\hline 8,5 & II & sasiCl & 2,10 & 25 & 8 & 70 \\
\hline 4,5 & IV & $\mathrm{MSa} / \mathrm{CSa}$ & 1,98 & 35 & 0 & 130 \\
\hline
\end{tabular}

\section{Calculation methodology}

\subsection{THE CALCULATION METHODS DESCRIPTION}

In the paper, for the subside through expansion calculation over the twin tube tunnel the following empirical and analytical formula were used: 
Peck:

$$
s=s_{\max } \exp \left(\frac{-y^{2}}{2 i^{2}}\right)
$$

where:

$\mathrm{y}$ - distance of the considered point from the tunnel axis [m], i - trough width parameter [-], $\mathrm{s}_{\max }-$ maximal settlements in the axis of the tunnel [m]

Oteo:

$$
s=\Psi \frac{\gamma D^{2}}{E}(0,85-v) \exp \left(\frac{-y^{2}}{2 i^{2}}\right)
$$

where:

$\Psi$ - empirical factor determine by the monitoring observation [-], D - tunnel diameter [m], E - Young modulus [MPa], $\gamma$ - unit weight $\left[\mathrm{kN} / \mathrm{m}^{3}\right], v-$ Poisson ratio [-]

Attewell and Woodman:

$$
s(x)=\frac{V_{s}}{\sqrt{2 \pi} \cdot i} \cdot \exp \left(-\frac{y^{2}}{2 i^{2}}\right) \cdot\left\{G\left[\frac{x-x_{i}}{i}\right]-G\left[\frac{x-x_{f}}{i}\right]\right\}
$$

where:

$\mathrm{x}$ - longitudinal position of the considered surface point $[\mathrm{m}], \mathrm{V}_{\mathrm{s}}$ - volume of the settlement trough per meter of tunnel advance $\left[\mathrm{m}^{3} / \mathrm{m}\right], \mathrm{x}_{\mathrm{i}}-$ initial position of the tunnel $[\mathrm{m}], \mathrm{x}_{\mathrm{f}}-$ position of the tunnel face $[\mathrm{m}], \mathrm{G}-$ Gauss distribution function, $\mathrm{P}_{\mathrm{s}}-$ total overload $\left[\mathrm{t} / \mathrm{m}^{2}\right]$

\section{Herzog:}

$$
S_{\max }=0,785\left(\gamma H+P_{s}\right)\left(\frac{D^{2}}{i E}\right)
$$

Sagaseta:

$$
s(x)=\frac{V_{L}}{2 \pi H}\left(1+\frac{x}{\sqrt{x^{2}+H^{2}}}\right)
$$


where:

$\mathrm{V}_{\mathrm{L}}$ - volume loss $\left[\mathrm{m}^{3} / \mathrm{m}\right], \mathrm{H}=\mathrm{Z}_{0}-$ distance between surface and axis of the tunnel [m], $\mathrm{K}$ - empirical factor depending of type of soil [-]

New i O'Reilly:

$$
s=s_{\max } \exp \left(\frac{-y^{2}}{2 i^{2}}\right)=\frac{V_{s}}{\sqrt{2 \pi} \cdot K \cdot z_{0}} \exp \left(\frac{-y^{2}}{2\left(K \cdot z_{0}\right)^{2}}\right)
$$

Verruijt and Brooker:

$$
s=4 \varepsilon r^{2}(1-v) \frac{H}{y^{2}+H^{2}}-2 \delta r^{2} \frac{H\left(x^{2}-H^{2}\right)}{\left(x^{2}+H^{2}\right)^{2}}
$$

where:

$\varepsilon$ - radial deformation [m], $\delta$ - ovality [-], r - radius of the tunnel [m], g-factor which determine gap in the tail void of the shield [-]

Longanathan and Poulos:

$$
s(y)=(1-v) \frac{H}{y^{2}+H^{2}}\left(4 g R+g^{2}\right) e^{-\left(\frac{1,38 y^{2}}{(H+R)^{2}}\right)}
$$

\subsection{THE RESULTS OF CALCULATIONS}

On the basis of presented empirical formulas (chapter 3.1) there were done several settlement calculation for the designated monitoring section with dedicated geotechnical layers position, tunnel geometry (given in chapter 2.1) and individual soil parameters. Outcomes for each section are combined all together at one graph Fig. $8 \div 10$. The graphs show distribution of the deformations on the both sides of the line axis both with total vertical deformations over each of twin tunnels. 


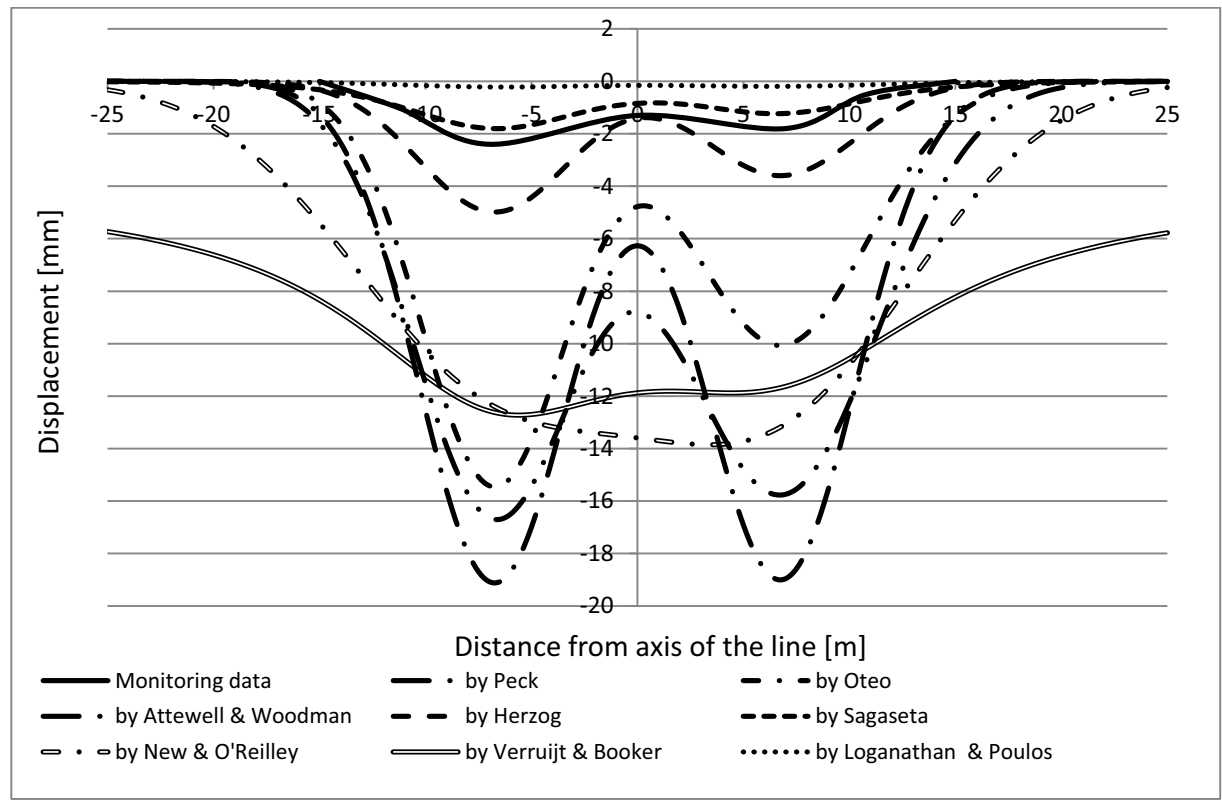

Fig. 8. Calculated deformations for twin tunnels in section no. 1101

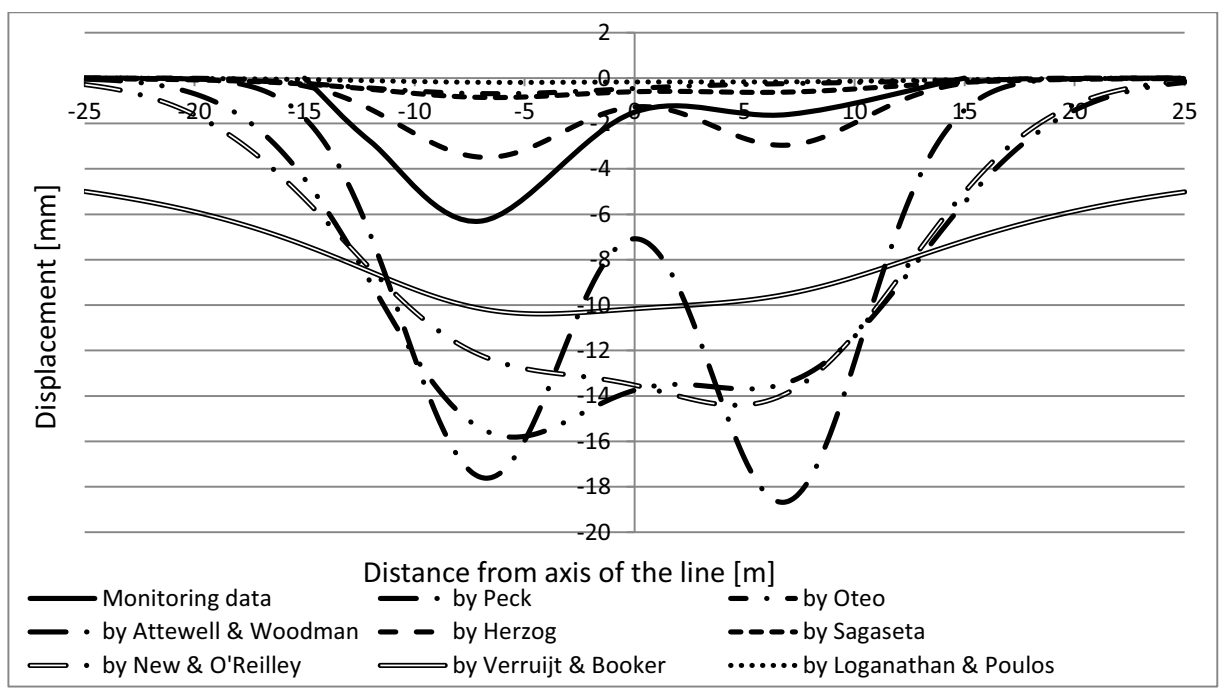

Fig. 9. Calculated deformations for twin tunnels in section no. 1104 


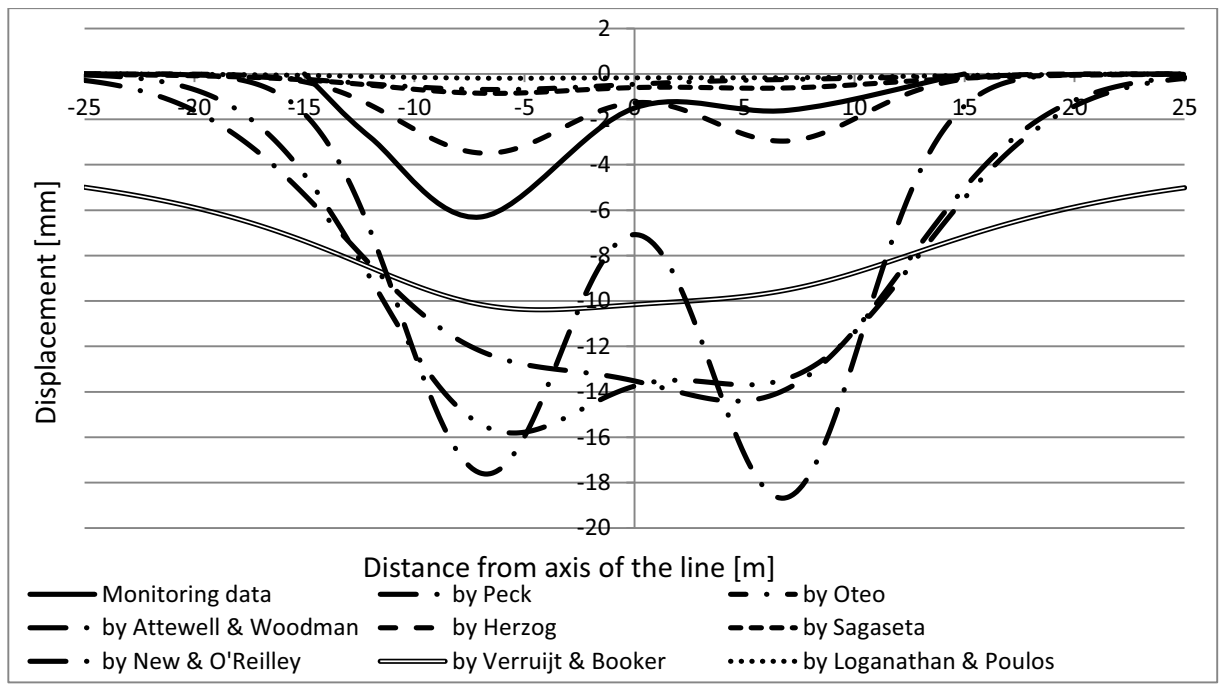

Fig. 10. Calculated deformations for twin tunnels in section no. 1106

\section{CONCLUSIONS}

As the graphs comparison shows, the superposition of subsidence for each independent tunnel calculated by most empirical formulas gives symmetric approach. Such empirical solution is the most popular prediction of the tunneling impact in the urban areas. Differences of the settlement trough depth between north and south tunnel, visible on the graphs (Fig. $8 \div 10$ ) is connected with different values of soil modulus, which was calculated as weighted average of the layers over each tunnel. Differences in the outcomes are typical in Herzoga [3] formula (3.4). Unsymmetrical settlement distribution in New \& O'Reilly [10] formula (3.6) comes from the criteria to determine inflection point on the settlement curve in comparison with soil above the tunnel.

On the basis of the analysis of the graphs (Fig. $8 \div 10$ ) it is visible:

- $\quad$ The biggest settlements give Attewell \& Woodman [1], New \& O'Reilley [10] and Peck [12] formulas with outcomes from $14 \mathrm{~mm}$ to $20 \mathrm{~mm}$;

- The minimum settlements give formulas proposed by Loganathan \& Poulkos [5], Sagaseta [13], Oteo [11] with outcomes up to $2 \div 3 \mathrm{~mm}$;

- Herzog's [3] method gives the closest solution to the real values of deformation; 
- There are similar displacement values for several methods like: Peck [12], Attewell \& Woodman [1], New \& O'Reilly [10]. This is because of quite similar algorithm used by this authors;

- Maximum transversal range of settlement trough is 30 to $50 \mathrm{~m}$ from the axis of the metro line depending of empirical method.

On the basis of monitoring data highlighted on the Fig. $8 \div 10$ it is clear that:

- Real displacement over first tunnel reach 0 to $5 \mathrm{~mm}$ and for second one up to $8 \mathrm{~mm}$, range of the settlement trough is about $30 \mathrm{~m}$ from metro line axis;

- There is no compatibility between empirical calculation and real deformation;

- Theoretical axial symmetry approach (superposition of the settlement trough over two separate tunnels) don't give outcomes convergent with real deformations - monitoring data show not symmetry settlement distribution. Deformations for second tunnels are bigger than for first one - even twice;

- In most cases analytical methods gives too law or too big values of deformations for twin tunnels made by TBM machine.

Analyzing outcomes of the calculations and conclusions above it is reasonable to look for better correlation between calculation methods and real deformations (numerical methods Kuszyk \& Sieminska-Lewandowska [4]) or to find modifications of already known empirical methods in adaptation to local soil conditions of the area or country. Such solution is proposed by several authors like Verruijt and Booker [15] or Clough and Schmidt [2].

\section{REFERENCES}

1. P.B. Attewell, J.P. Woodman, "Predicting the dynamics of ground settlements and its derivatives caused by tunneling in soil", Ground Engineering 15(8), pp 13-22, 1982.

2. G.W. Clough, B. Schmidt, "Design and performance of excavation and tunnels in soft clay", Soft clay engineering, Elsevier, Amsterdam, pp 569-634, 1981.

3. M. Herzog, "Die setzungsmulde über seicht liegenden tunnel", Berlin, pp 375-377, 1985.

4. R. Kuszyk, A. Siemińska-Lewandowska, "Volume loss and settlement trough in Warsaw II line", ITA-AITES World Tunnel Congress, Underground - the way to the future, Geneva, 2013.

5. N. Longanathan, H.G. Poulos, "Analytical prediction for tunneling induced ground movements in clays", Journal of Geotechnical and Geoenvironmental Engineering 124 (9), pp 846-856, 1998.

6. R.J. Mair, "Tunneling in urban areas and effects on infrastructure. Advances in research and practice", Muir Wood Lecture, ITA-AITES materials, 2011.

7. M. Mitew-Czajewska "Evaluation of deep excavation impact on surrounding structures-a case study", Underground Infrastructure of Urban Areas 3, CRC Pess/Taylor \& Francis Group, pp 161-172, 2015.

8. M. Mitew-Czajewska, "Evaluation of Hypoplastic Clay model for deep excavation modelling", Archieves of Civil Engineering, Vol. 62, nr 4/I, pp 73-86, 2016.

9. M.Mitew-Czajewska "Parametric study of deep excavation in clays", Bulletin of the Polish Academy of Sciences, Technical Sciences, Vol. 66, No. 5, pp 747-754, 2018. 
10. B.M. New, M.P. O'Reilly, "Settlement above tunnels in the United Kingdom - their magnitude and prediction", Proceedings of the Tunneling 82 Conference, Brighton, pp 173-181, 1982.

11. C.S. Oteo, "The Madrid Model: A Simplified Approach to the Tunnel Subsidence Estimation", International Conference on Mathematical and Statistical Modeling in Honor of Enrique Castillo, Spain. UCLM, 2006.

12. R.B. Peck, "Deep excavations and tunneling in soft ground", Proceedings of the 7 th International Conference on Soil Mechanics and Foundation Engineering, Mexico, Vol. 4, pp 225-290, 1969.

13. C. Sagaseta, "Analysis of undrained soil deformation due to ground loss", Géotechnique 37(3), pp 301-320, 1987.

14. A.E. Siemińska-Lewandowska, M. Mitew-Czajewska "The effect of deep excavation on surrounding ground and nearby structures", Proceedings of the 6th International Symposium, Shanghai, China, Geotechnical Aspects of Underground Construction in Soft Ground, CRC Press/Balkema, pp 201-206, 2009.

15. A. Verruijt, J.R. Booker, "Surface settlements due to deformation of a tunnel in an elastic half plane", Géotechnique 46(4), pp 753-757, 1996.

16. Instruktion ITB no. 376/2002. Ochrona zabudowy w sąsiedztwie głębokich wykopów.

17. ITA-AITES, "Settlements induced by tunneling in Soft Ground", Tunnelling and Underground Space Technology 22 (2007), pp 119-149, 2006. 


\section{LIST OF FIGURES AND TABLES:}

Fig. 1. Cross section of twin tube metro tunnel

Rys. 1. Przekrój dwóch tuneli jednotorowych metra

Fig. 2. Geological profile

Rys. 2. Przekrój geologiczny

Fig. 3. Typical full monitoring section

Rys. 3. Układ typowej sekcji monitoring

Fig. 4. Location of the monitoring sections no. 1101, 1104 and 1106

Rys. 4. Lokalizacja sekcji monitoring nr 1101, 1104 i 1106

Fig. 5. Geological scheme of the section no. 1101

Rys. 5. Schemat warunków geologicznych dla sekcji nr 1101

Fig. 6. Geological scheme of the section no. 1104

Rys. 6. Schemat warunków geologicznych dla sekcji nr 1104

Fig. 7. Geological scheme of the section no. 1106

Rys. 7. Schemat warunków geologicznych dla sekcji nr 1106

Fig. 8. Calculated deformations for twin tunnels in section no. 1101

Rys. 8. Obliczeniowe osiadania nad dwoma tunelami w sekcji nr 1101

Fig. 9. Calculated deformations for twin tunnels in section no. 1104

Rys. 9. Obliczeniowe osiadania nad dwoma tunelami w sekcji nr 1104

Fig. 10. Calculated deformations for twin tunnels in section no. 1106

Rys. 10. Obliczeniowe osiadania nad dwoma tunelami w sekcji nr 1106

Tab. 1. Soil properties in section no. 1101

Tab. 1. Parametry gruntu w sekcji nr 1101

Tab. 2. Soil properties in section no. 1104

Tab. 2. Parametry gruntu w sekcji nr 1104

Tab. 3. Soil properties in section no. 1106

Tab. 3. Parametry gruntu w sekcji nr 1106 


\section{ANALIZA NIECKI OSIADAŃ NAD DWOMA TUNELAMI METRA DRĄŻONYMI TARCZĄ TBM}

Słowa kluczowe: tunele metra, obliczanie osiadań, niecka osiadań, tarcza TBM EPB

\section{STRESZCZENIE:}

Jednym z istotnych aspektów drążenia tuneli tarczami zmechanizowanymi typu TBM w warunkach gęstej zabudowy miejskiej jest oszacowanie możliwej do powstania niecki osiadań na powierzchni terenu, powstałej w wyniku prowadzonych robót oraz jej wpływ na infrastrukturę podziemną i naziemną. W artykule przedstawiono przykład tuneli drążonych w typowych, czwartorzędowych gruntach polodowcowych Polski. Średnica zewnętrzna tunelu wynosi $6,5 \mathrm{~m}$ przy grubości nadkładu od 5 do $8 \mathrm{~m}$ i rozstawie tuneli $14 \mathrm{~m}$ od osi. W omawianym przypadku, z uwagi na występowanie gruntów mineralnych oraz wysoki poziom zwierciadła wody gruntowej, wykonawca zastosował do drążenia tuneli tarczę zmechanizowaną TBM typu EPB - wyrównanych ciśnień gruntowych.

$\mathrm{W}$ artykule przedstawiono wyniki obliczeń osiadań powszechnie stosowanymi wzorami empirycznymi podanymi $\mathrm{W}$ literaturze przez szereg autorów dla różnych warunków gruntowych na świecie. Wykazano stosunkowo duże zróżnicowanie wyników w zależności od przyjętej metody. Jednocześnie dla porównania przedstawiono wyniki osiadań pomierzonych rozbudowanym systemem monitoringu. Jako reprezentatywny wybrano odcinek tuneli o długości $502 \mathrm{~m}$, gdzie zainstalowane zostały 22 sekcje monitoringowe. W zestawieniu końcowym pokazano wspólnie rozkład niecki osiadań wynikający z metod obliczeniowych oraz rzeczywistych pomiarów. Jako wnioski końcowe wykazano główną rozbieżność w wynikach dotyczącą asymetryczności rzeczywistego rozkładu osiadań w stosunku do metod empirycznych, które z uwagi na stosowane uproszczenia, dają odbicie symetryczne rozkładu osiadań przy analizie dwóch tuneli równocześnie. Jednocześnie autorzy zalecają, by dla dokładniejszej analizy rozkładu osiadań nad dwoma tunelami stosować metody numeryczne lub zmodyfikowane metody empiryczne dostosowane do lokalnych warunków gruntowych. 